\title{
ステンレス鋼管における水蒸気酸化スケールの 生成剝離挙動
}

\author{
森田 聡*，大塚伸夫** \\ * 関西電力株式会社 総合技術研究所 \\ ** 住友金属工業株式会社 総合技術研究所
}

\begin{abstract}
The Spalling of Steam-Grown Oxide Scale from SUS 321 HTB Tube Steel
Akira Morita* and Nobuo Otsuka**

* Technical Research Center, The Kansai Electric Power Company, Inc.

** Corporate R\&D Laboratories, Sumitomo Metal Industries, Ltd.
\end{abstract}

\begin{abstract}
It is well known that oxide scales formed on the steam side of the superheater and reheater tubes in power generation boilers sometimes spall after a long time operation. Spalling of oxide scales may cause blockage of the tubes as well as erosion of the first stage nozzles and buckets of the turbines. This study was carried out to obtain the knowledge about the spalling behavior of the steam oxide scale in stainless-steel tubes. SUS $321 \mathrm{HTB}$ tube specimens were heated in steam atmosphere at $600-750^{\circ} \mathrm{Cfor}$ more than $300 \mathrm{~h}$, and then cooled with $50-170^{\circ} \mathrm{Ch}^{-1}$. Mass change and cross section of specimens were examined to evaluate the scale spalling. Obtained results are summarized as follows:

(1) Micro-cracks were observed along the interface between the outer and inner oxide scales for all specimens but macroscopic spalling of the outer scale occurred only for the specimens heated at $>700^{\circ} \mathrm{C}$.

(2) Extension of the interface separation was independent of heating temperature and cycles, and increased with inner scale thickness.

(3) Spalling of outer oxide scales was strongly affected by heating temperature and heating cycles.
\end{abstract}

Key words : steam oxide scale, spalling, SUS $321 \mathrm{HTB}$, weight of spalled scale, inner scale thickness.

1. 緒

\section{言}

ボイラ用過熱器管・再熱器管などの管内面に水蒸気に よる酸化スケールが生成することは古くから知られてい $3^{1), 4)}$. 水蒸気酸化スケールが剥離すると, 例えばボイ ラチューブUベンド部に堆積して蒸気流路が閉塞する ことによるチューブの過昇温や, 剥離したスケールが蒸 気タービンまで飛散することによるタービン翼などのエ ロージョンといった不具合を生じる.このため, ボイラ 材のスケール成長挙動や剥離挙動については, これまで にも多くの研究がなされている1)-9).

代表的なボイラ材である $\mathrm{Cr}-\mathrm{Mo}$ 鋼やオーステナイト 系ステンレス鋼の水蒸気酸化スケールが内層および外層 の 2 層からなること, スケールの成長速度が時間に対し て放物線則に従うことはよく知られており, 放物線速度 定数の温度依存性についても多くのデータが報告されて いる.さらに，スケール厚さが厚くなるほどスケール剥 離が生じやすくなることも報告されている。

炭素鋼や $\mathrm{Cr}-\mathrm{Mo}$ 鋼ではスケール剥離は内層スケール と基材との界面で生じることが多い7). Cr-Mo 鋼では, 冷却過程でこの界面にスケールと基材との熱膨張係数の 違いに起因する引張応力が生じ, この引張応力とスケー ル密着力（実缶のスケール剥離試験より実測）との比較 により剥離挙動を定性的ではあるが評価できることが報

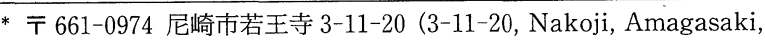
661-0974 Japan)

** 干 660-0891 尼崎市扶桑町 1-8 (1-8, Fuso-cho, Amagasaki, 6600891 Japan)
}

告されている，一方，ステンレス鋼の場合，剥離が内層 スケールと外層スケールの界面で生じることから $\mathrm{Cr}-$ Mo 鋼の場合と同様のスケール剥離評価は難しい.

本研究では, ステンレス鋼管の水蒸気酸化スケールの 生成・剥離挙動に関する知見を得る目的で，主として実 験室での検討を行った。まず，加熱温度や時間を種々に 変えた条件でステンレス鋼管にスケールを生成させ，次 いでさまざまな冷却条件下におけるスケール剥離挙動を 観察した。 スケール剥離を代表するパラメータとしてス ケール剥離量とミクロ観察によるスケール剥離率（後 述）に着目し，スケール厚さとの相関を調査した。ま た，スケール剥離挙動の力学的評価に資する目的で，水 蒸気酸化スケールのスケール密着力の測定試験を実施し た. 最後に，スケールと基材の熱膨張係数の差に基づく 若干の力学的検討を行った.

\section{2. スケール生成剥離試験}

\section{1 試 験 方 法}

代表的なボイラ用ステンレス鋼の一つである SUS 321 HTB 鋼を供試材として用いた. 実機で使用さ

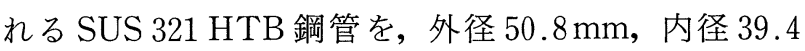
$\mathrm{mm}$, 幅 $40 \mathrm{~mm}$ の管状試験片に加工し, 酸洗 (3\% HF $+10 \% \mathrm{HNO}_{3}$ 溶液）により機械加工の影響を除去しア セトンによる脱脂洗浄を行った後, 熱風乾燥して試験に 供した。

水蒸気酸化試験装置の系統図を Fig. 1 に示す。アル ゴンにより脱気した水タンクからポンプで一定量の水を 流し，それを蒸気発生装置で加熱し試験炉に水蒸気を流 


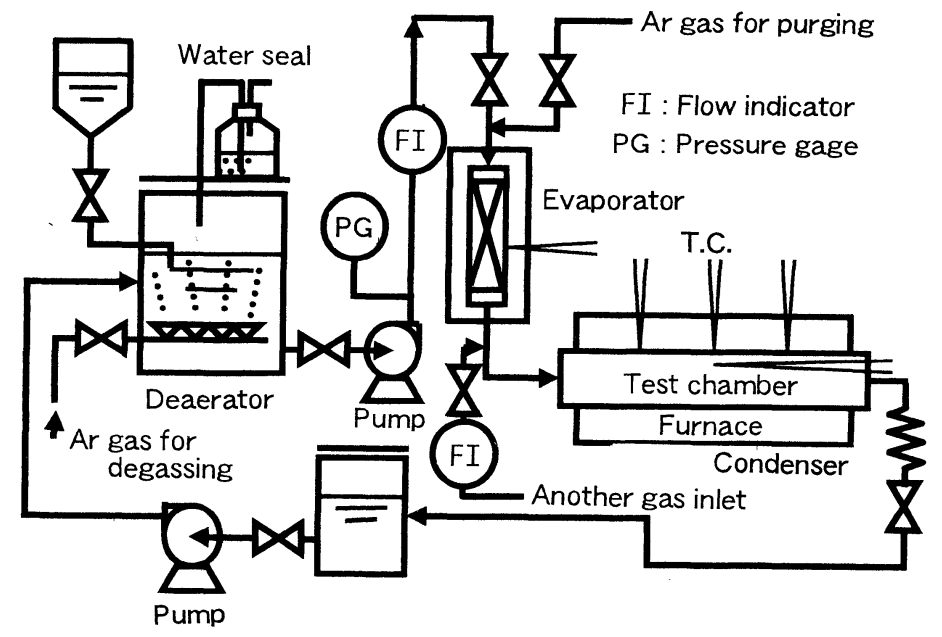

Fig. 1 Schematic diagram of the steam oxidation test apparatus used in this study.

Table 1 Experimantal Condition $\left({ }^{*},{ }^{* *}\right.$ : see text $)$.

\begin{tabular}{|c|c|c|c|c|}
\hline $\begin{array}{r}\text { Cooling } \\
\text { Rate } \\
\text { Heat Temp. }\end{array}$ & $50^{\circ} \mathrm{Ch}^{-1}$ & $110^{\circ} \mathrm{Ch}^{-1}$ & $130^{\circ} \mathrm{Ch}^{-1}$ & $170^{\circ} \mathrm{Ch}^{-1}$ \\
\hline $600^{\circ} \mathrm{C}$ & $1000 \mathrm{~h}^{*}$ & & & $\therefore$ \\
\hline $650^{\circ} \mathrm{C}$ & $1000 \mathrm{~h}$ & & & \\
\hline $700^{\circ} \mathrm{C}$ & $\begin{array}{r}300 \mathrm{~h} \\
1000 \mathrm{~h}\end{array}$ & $\begin{array}{r}300 \mathrm{~h} \\
1000 \mathrm{~h}\end{array}$ & $\begin{array}{l}300 \mathrm{~h} \\
1000 \mathrm{~h} \\
3000 \mathrm{~h} \\
3000 \mathrm{~h}+2000 \mathrm{~h} \\
3000 \mathrm{~h}+2000 \mathrm{~h}+1000 \mathrm{~h} * *\end{array}$ & \\
\hline $750^{\circ} \mathrm{C}$ & $\begin{array}{r}720 \mathrm{~h} \\
1000 \mathrm{~h} \\
\end{array}$ & & & $\begin{array}{r}720 \mathrm{~h} \\
1000 \mathrm{~h} \\
\end{array}$ \\
\hline
\end{tabular}

し，復水してタンクに戻る閉回路により構成されてい る. 本試験では, 水蒸気流速は $7 \mathrm{~cm} / \mathrm{s}$ （流量は水換算 で $5 \mathrm{~cm}^{3} / \mathrm{min}$ ), 溶存酸素量は $20 \sim 30 \mathrm{ppb}$ に保持した。

加熱温度，時間および冷却速度を実験パラメータとし て変化させた. Table 1 亿実験条件の一覧を示す. 表中 の冷却速度は, 冷却開始後最初の 1 時間の平均冷却速度 を記載した。表中*欄は $600^{\circ} \mathrm{Cで} 1000$ 時間加熱後 $50^{\circ} \mathrm{C} /$ h で泠却する実験を実施したことを示している. $700^{\circ} \mathrm{C}$, $130^{\circ} \mathrm{C} / \mathrm{h}$ の条件では, 加熱冷却を 2 ないし 3 回繰り返す 条件でも実験を行っており，例えば，**は 3000 時間加 熱して, $130^{\circ} \mathrm{C} / \mathrm{h}$ で室温まで泠却し，さらに 2000 時間 加熱して $130^{\circ} \mathrm{C} / \mathrm{h}$ で室温まで冷却した後, 再び 1000 時 間加熱して $130^{\circ} \mathrm{C} / \mathrm{h}$ で冷却したことを意味している. なお，表中に示す 15 条件とも，試験管は各 3 個ずつ実 験に用いた。

試験終了後, 管内に剝離して堆積している水蒸気酸化 スケールの重量を測定し，この值をスケール剝離量と定 義した。また，管状試験片を軸方向に 2 分割し，その断 面を光学顕微鏡で観察し，内層スケール厚さを測定し た.

\section{2 試 験 結 果}

$600 \sim 750^{\circ} \mathrm{C}$ の 4 条件の温度で 1000 時間加熱した後, $50^{\circ} \mathrm{C} / \mathrm{h}$ で冷却した 4 条件での試験結果を，スケール剥 離量と加熱温度との関係で Fig. 2 に示す。この条件で は，750 ${ }^{\circ} \mathrm{C} て ゙$ 加熱した場合にはスケール剥離を生じたが，

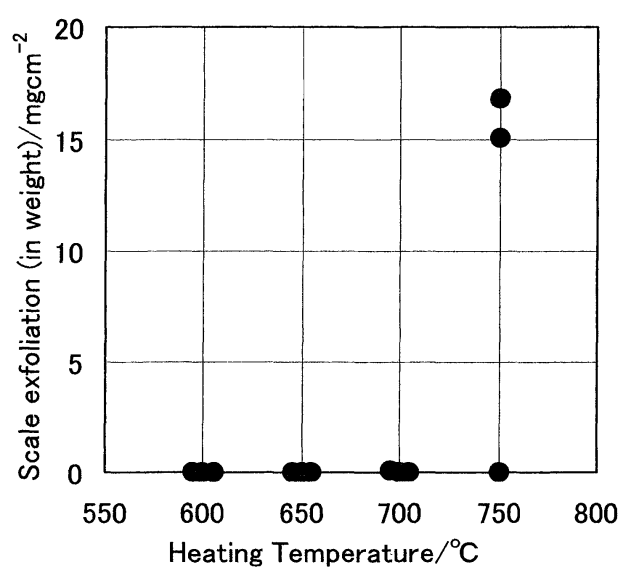

Fig. 2 Influence of the heating temperature on the scale exfoliation SUS 321 HTB tube steel. (Heated for $1000 \mathrm{~h}$, cooling rate of $50^{\circ} \mathrm{C} / \mathrm{h}$ down to $500^{\circ} \mathrm{C}$ ).

$700^{\circ} \mathrm{C}$ 以下の加熱温度では剝離を生じなかった。また, 同じ試験結果をスケール㓦離量と内層スケール厚さの関 係で Fig. 3 に示す. Fig. 3 より, $750^{\circ} \mathrm{C} て ゙$ 加熱した試験 片のうち 2 つは内層スケールが約 $50 \mu \mathrm{m}$ になった時点 で剝離を生じた。他の剝離を生じなかった試験片につい ても $20 \mu \mathrm{m} \sim 60 \mu \mathrm{m}$ 程度の内層スケールが生成してい た.

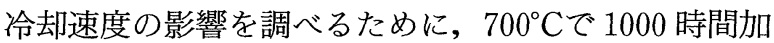




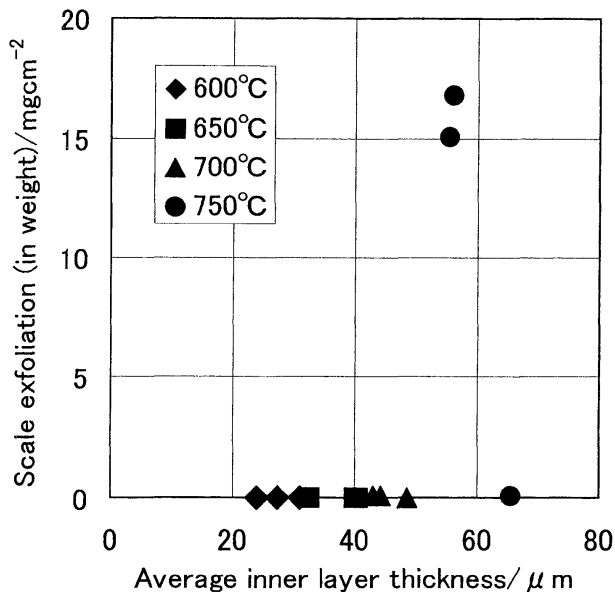

Fig. 3 Influence of the average inner layer thickness on the scale exfoliation of SUS 321 HTB tube steel. (Heated for 1000h, cooling rate of $50^{\circ} \mathrm{C} / \mathrm{h}$ down to $500^{\circ} \mathrm{C}$ ).

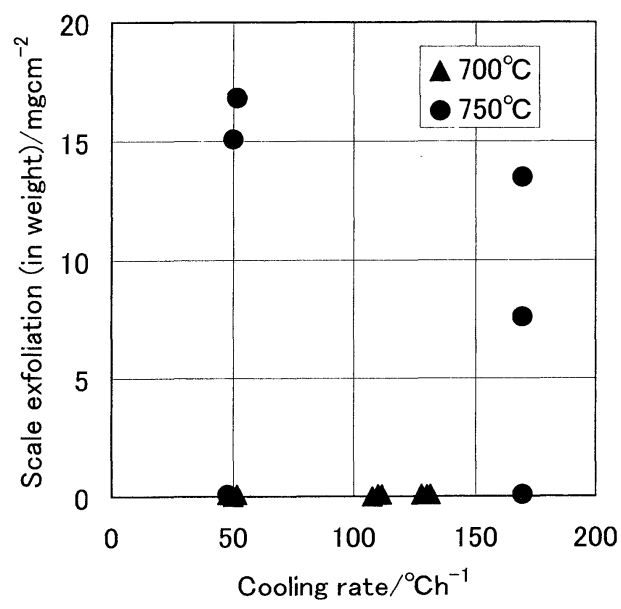

Fig. 4 Influence of the cooling rate on the scale exfoliation SUS 321 HTB tube steel.

熱後, $50^{\circ} \mathrm{C} / \mathrm{h}, 110^{\circ} \mathrm{C} / \mathrm{h}, 130^{\circ} \mathrm{C} / \mathrm{h}$ の 3 通りの速度で冷 却した試験結果および $750^{\circ} \mathrm{Cで} 1000$ 時間加熱後, $50^{\circ} \mathrm{C} /$ $\mathrm{h}$ と $170^{\circ} \mathrm{C} / \mathrm{h}$ の 2 通りの速度で冷却した試験結果をまと めて, スケール剥離量と冷却速度の関係で Fig. 4 に示 す. $700^{\circ} \mathrm{C}$ に加熱した試験片では冷却速度にかかわりな くスケール剝離は生じなかったが， $750^{\circ} \mathrm{C} に$ 加熱した試 験片ではいずれの冷却速度でも顕著なスケール剥離が生 じた. Fig. 4 より，スケール剥離量に及ぼす冷却速度の 明瞭な影響は認められなかった。同じ試験結果をスケ一 ル剝離量と内層スケール厚さの関係で整理したものを Fig. 5 に示す. Fig. 5 および Fig. 3 より, 内層スケール 厚さが $40 \sim 50 \mu \mathrm{m}$ 程度になるまではスケール剥離を生 じず，スケール厚さがこれよりも厚くなった時点でスケ ールの剝離が認められる。

加熱・冷却繰り返しの影響を調べるために, $700^{\circ} \mathrm{Cで}$ 加熱後, $130^{\circ} \mathrm{C} / \mathrm{h}$ で冷却した 5 条件の試験結果をまとめ てスケール剥離量と加熱時間（冷却回数）の関係で整理 したものを Fig. 6 に示す. Fig. 6 より，加熱・冷却繰り 返し数が多いほどスケール剥離量が多くなる傾向がみら れるが，同時に加熱時間が長いほどスケール剥離量が多

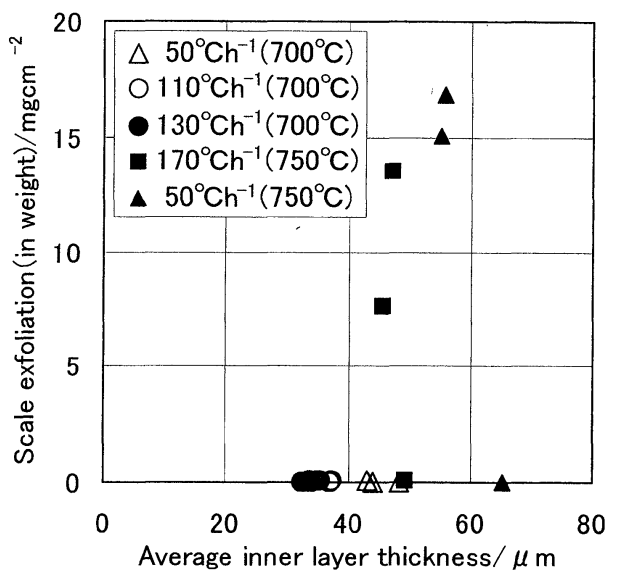

Fig. 5 Influence of the average inner layer thickness on the scale exfoliation of SUS 321 HTB tube steel.

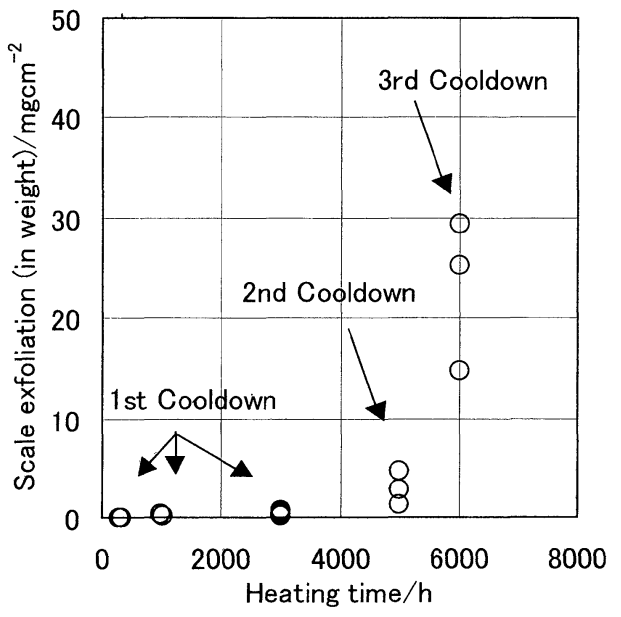

Fig. 6 Influence of the heating time on the scale exfoliation of SUS 321 HTB tube steel at $700^{\circ} \mathrm{C}$.

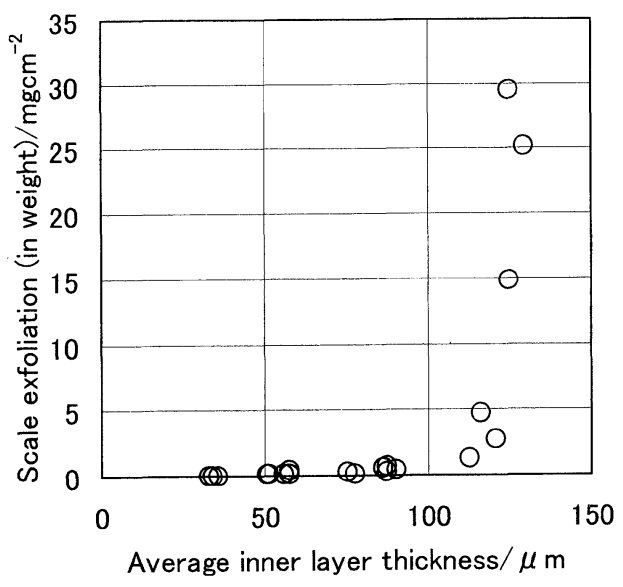

Fig. 7 Influence of the average inner layer thickness on the scale exfoliation of SUS $321 \mathrm{HTB}$ tube steel at $700^{\circ} \mathrm{C}$.

くなると解釈することも可能である。また，Fig. 7 のよ うに，スケール剥離量と内層スケール厚さの関係で整理 すると，この条件ではスケール剥離は内層スケールが 


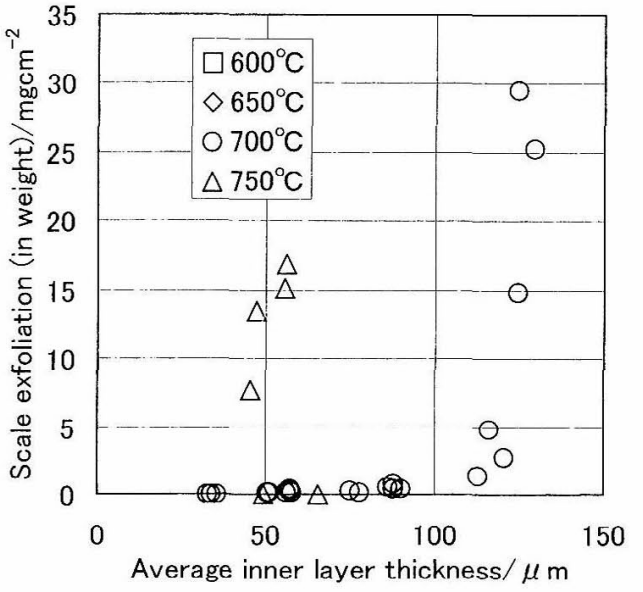

Fig. 8 Influence of the average inner layer thickness on the scale exfoliation of SUS 321 HTB tube steel.

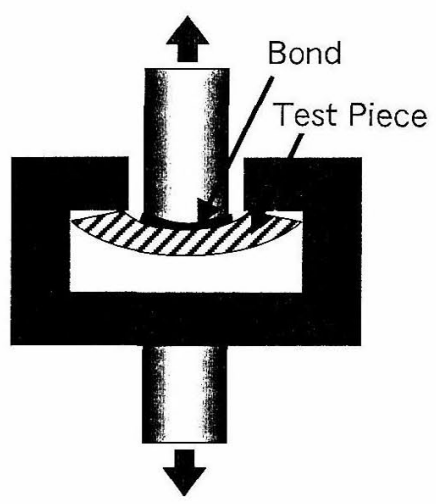

Fig. 9 Tensile test used for measuring oxide scale adhesion.

$100 \mu \mathrm{m}$ を超える場合に生じる傾向を示した。

Table 1 に示すすべての試験結果をまとめてスケール 剥離量と内層スケール厚さの関係でFig. 8 に示す。本 試験では，加熱温度が $650^{\circ} \mathrm{C}$ 以下では顕者な剥離は生じ なかった。加熱温度が $700^{\circ} \mathrm{C}$ 場合スケール剥離はおうう む和内層スケール厚さが約 $100 \mu \mathrm{m}$ を超える条件下で生 じたが， $750^{\circ} \mathrm{C}$ 場合には，50 $\mu \mathrm{m}$ 程度でも剝離を生じ ており，スケールの剥離は内層スケール厚さのみでは説 明できなかった。

\section{3. スケール密着力試験}

\section{1 試 験 方 法}

実機の上部隔壁管, 上部分割壁管, 過熱器管, 再熱器 管より抜管した SUS 321 HTB，SUS 316 HTB, SUS $347 \mathrm{HTB}$ の 3 鋼種を試験に供した。供試材より切 削加工により長さ $20 \mathrm{~mm}$ の弧状試験片抢よび管内径に 合った治具 $\phi 10 \mathrm{~mm}$ Fig. 9 のとおり作製した。供試 材管内面側のスケール生成部に $\phi 10 \mathrm{~mm}$ の治具を接着 剂にて貼り付け, 引張試験機にて引張強度を測定した.

\section{2 試 験 結 果}

供試材管内面に生成している内層スケール厚さの測定 を行ったところ, SUS $321 \mathrm{HTB}$ は最大で約 $50 \mu \mathrm{m}$ 程

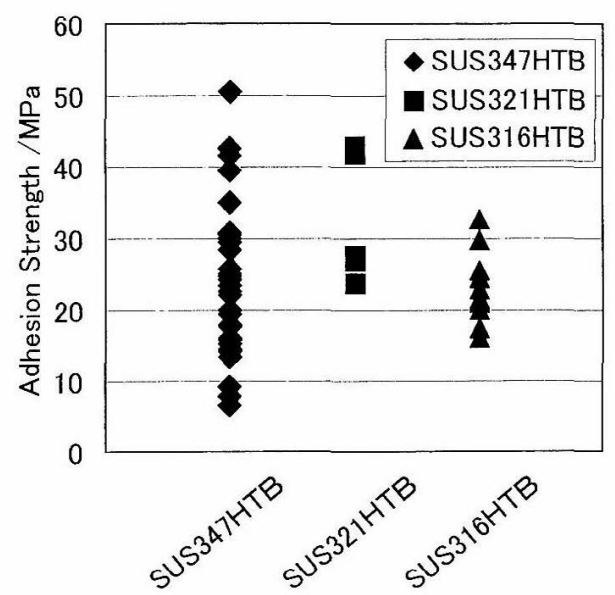

Fig. 10 Adhesion strength of steam-growth oxide scale formed on boiler tubes in commercial plants.
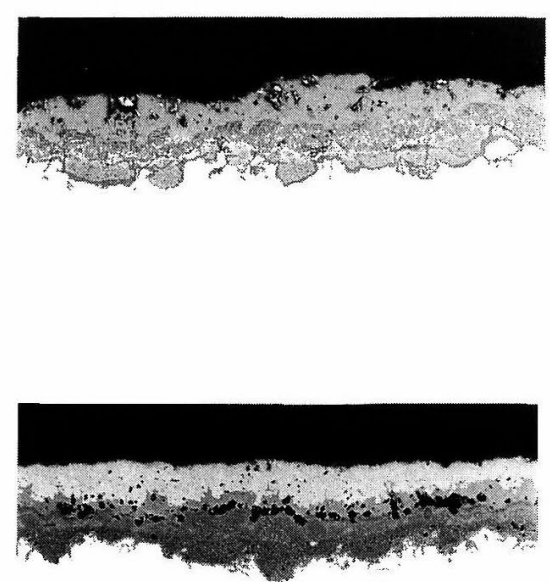

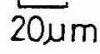

Fig. 11 Optical micrographs for the cross section of steam-growth oxide scale on SUS 347 HTB stainless steel tested for adhesion-strength measurements. (Upper figure specimen showed maximum adhesion strength; lower figure specimen resulted in minimum adhesion strength).

度, SUS 347 IITB も最大で約 $50 \mu \mathrm{m}$ 程 度, SUS 316 $\mathrm{HTB}$ は最大で $160 \mu \mathrm{m}$ 程度の水蒸気酸化スケールの生 成が認められた。また，SUS 321 HTBの一部で最大 $110 \mu \mathrm{m}$ の粒界酸化が見られた。X 線回折の結果，ほぼ すべての供試材の内層スケールから $\mathrm{Fe}_{2} \mathrm{O}_{3}$ おび $(\mathrm{Fe}, \mathrm{Cr})_{3} \mathrm{O}_{4}$ が検出された. Fig. 10 に密着強度測定結 果を示す. スケールの密着強度は $7.2 \sim 45.1 \mathrm{MPa}$ と大 きなばらつきを示したが，多くのスケールでは 15.0 $\mathrm{MPa}$ 以上の密着強度を有していた。ミク口観察の結果 を Fig. 11 に示す. Fig. 11 より, 密着強度が低い供試材 では，内層スケールと外層スケールの界面で空孔が多く 


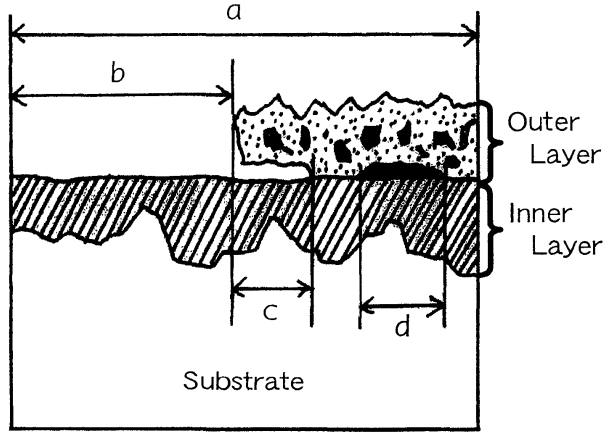

Fig. 12 Definition of the "microscopic detachment" of outer oxide layer introduced in this study. ( $\mathrm{a}$; interface length, $\mathrm{b}+\mathrm{c}+$ $d$; length of detachment).

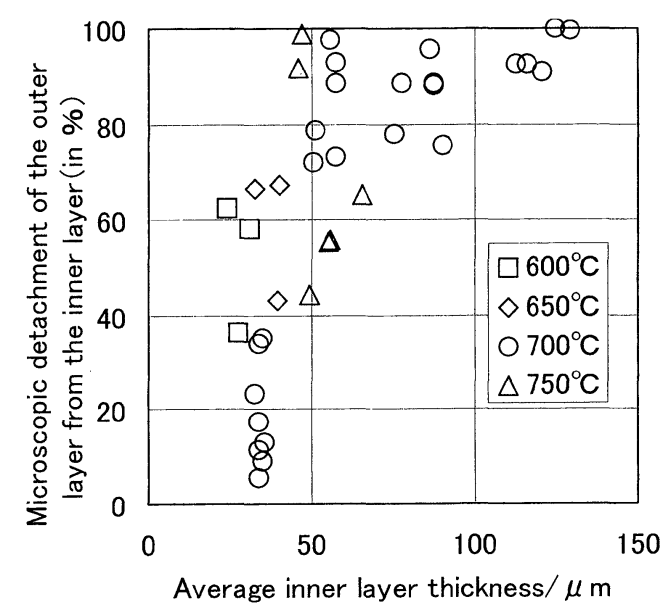

Fig. 13 Microscopic detachment (in \%) vs. average inner layer thickness.

存在していることがわかり，したがって，この空孔がス ケール密着強度低下の原因の一つと考えられる。

\section{4. 考察}

\section{1 外層スケール断面剝離率}

試験片断面を $1 \mathrm{~mm}$ ピッチで 20 視野, 光学顕微鏡 （500 倍）で観察し，スケール剝離部（外層スケールが 存在しない部分）および外層スケールは存在するが内層 スケールに密着せずに浮いている部分を含めてその長さ を測定し，その総延長と測定した部位の総延長との比 を，外層スケール断面剥離率と定義した. Fig. 12 の例 で示すと，外層スケールが内層スケールと密着していな い部分 $(b+c+d)$ を総延長 $(a) て ゙$ 除した值が外層スケー ル断面剥離率と計算される。

本研究で取得した全データを，外層スケール断面剥離 率と内層スケール厚さの関係で Fig. 13 に示す. Fig. 8 からわかるように加熱温度 $700^{\circ} \mathrm{C}$ 以下では内層スケール 厚さが $100 \mu \mathrm{m}$ 程度以下ではほとんどスケール剥離を生 じなかったが，このような場合でも外層スケール断面剥 離率はかなり大きな值を示しており，ミクロ的なスケー ル剥離は生じていたことがわかる.また，Fig. 8 の整理 では加熱温度 $700^{\circ} \mathrm{C}$ 以下と $750^{\circ} \mathrm{C}$ で外層スケールの剥離 に対する内層スケール厚さの影響は異なるが, Fig. 13
に示したように，ミクロ的な剥離発生挙動に対する加熱 温度や加熱冷却の繰り返しの影響はなく，ミク口的な剥 離は主として内層スケール厚さに支配されている可能性 が示唆される.

Fig. 6, Fig. 7 および Fig. 13 より，加熱冷却を 3 回繰 り返した試験と 2 回繰り返した試験とでは内層スケール 厚さや外層スケール断面剥離率はほぼ同じであるが，ス ケール剝離量は前者の方が顕著に大きいことがわかる. また, Fig. 8 と Fig. 13 から, 加熱温度が $750^{\circ} \mathrm{C}$ 場合 と $700^{\circ} \mathrm{C}$ 以下の場合では, 内層スケール厚さや外層スケ ール断面剥離率が同じでもスケール剥離量は顕著に異な ることがわかる．これらのことから，ミクロ的なスケー ル剥離がマクロ的なスケール剥離に移行する過程では, 加熱温度や加熱冷却の繰り返しが影響を及ぼしている可 能性が示唆される。

蒸気温度 $565^{\circ} \mathrm{C}$ の実缶ボイラのステンレス鋼を調査 し, スケール剥離発生確率と内層スケール厚さが 25～40 $\mu \mathrm{m}$ の範囲内での剝離発生確率が 13\%（8 本中 1 本でマクロなスケール剥離発生)， $40 \sim 60 \mu \mathrm{m}$ の範囲内 での剥離発生確率が 20\% (20 本中 4 本)， $60 \sim 80 \mu \mathrm{m}$ の 範囲内での㓦離発生確率が $28 \%$ (18 本中 5 本) と内層 スケール厚さが増すにしたがって剥離発生確率も増大 し, 内層スケール厚さ $120 \mu \mathrm{m}$ 以上では剥離発生確率が 100\%（7 本中 7 本）となっている. 一方, 本研究では 加熱温度 $700^{\circ} \mathrm{C}$ 以下で加熱冷却の繰り返しが 1 回の場合 には内層スケール厚さ $80 \mu \mathrm{m}$ 以下ではマクロな剥離は 生じておらず (Fig. 8), この点からも加熱冷却の繰り 返し（実缶ボイラでは多くの起動停止を有する）がマク ロな剥離挙動に影響を及ぼしている可能性が示唆され る.

\section{2 スケール剥離の力学的評価の試み}

$\mathrm{Cr}-\mathrm{Mo}$ 鋼におけるスケール剝離（内層スケールと基 材との界面での剥離）挙動が, 冷却過程でスケールと基 材との熱膨張係数差により界面に生じる引張応力とスケ ール密着力（本論文の 3 節と同様の方法で実験的に測 定）との比較により，ある程度定量的に評価できること が報告されている2．ステンレス鋼の場合スケール剥離 は外層スケールと内層スケールの界面で生じるが, 内層 スケールと基材との界面に生じる応力が何らかの原因で 内層と外層スケールの界面に応力を引き起こす可能性も 考えられるため，スケールと基材との熱膨張係数差によ る応力をステンレス鋼の場合について以下に評価してみ た.

$600^{\circ} \mathrm{C}$ からの冷却によりステンレス鋼の水蒸気酸化ス ケールに作用する熱ひずみが，文献 ${ }^{2)}$ に試算されてい

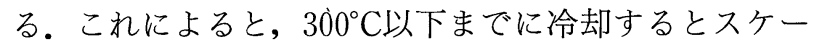
ルには圧縮ひずみが働くが，400〜 $500^{\circ} \mathrm{C}$ 付近に冷却さ れた時点でスケールに約 $0.03 \%$ 最大引張ひずみが生 じる. スケールのヤング率を $60 \mathrm{GPa}^{1)}$ とするとスケー ルに生じる最大引張応力は $\sigma_{\mathrm{T}}=18 \mathrm{MPa}$ と算出される. 内層スケールと基材の界面に生じる応力 $\sigma_{\mathrm{r}}$ は, 管内半 径を $r$, スケール厚さを $d$ とすると,

$$
\sigma_{\mathrm{r}}=\sigma_{\mathrm{T}} d / r
$$

で表される.この式に $r=19.7 \mathrm{~mm}, d \fallingdotseq 0.1 \mathrm{~mm}$ を代 入すると $\sigma_{\mathrm{r}} \fallingdotseq 0.1 \mathrm{MPa}$ となり, Fig. 10 に示すスケール 
密着力よりはるかに小さい応力しか発生しないと評価さ れた.

以上のように，スケールと基材の熱膨張係数の違いと (1) 式との組み合わせでは，ステンレス鋼のスケール剝 離は説明できないことが明らかとなった。(1) 式の評価 によれば界面全体に一様な応力が作用することになり， この場合 $\sigma_{\mathrm{r}}$ がスケール密着力を超えるとスケール剥離 が生じると予想される。ところが本試験によれば，ステ ンレス鋼のスケール剥離の場合まずミクロな剥離が多数 生じ（Fig. 13）, これらが合体することによりマクロな 剥離が発生すると考えられる。したがって，スケールと 基材の熱膨張係数の違いによりスケール剥離を説明しよ うとする場合，(1)式ではなく，スケールや基材内での 微視的な応力分布をより正確に反映した手法が求められ るのではないかと示唆される。

\section{5. 結}

言

オーステナイト系ステンレス鋼 SUS 321 HTB を供 試材として, 水蒸気酸化スケールの生成および剥離挙動 に関する実験的検討を行い，以下の結論を得た。

（1）冷却過程においてマクロなスケール剥離を生じて いない場合でも，外層スケールの浮きなどのミクロなス ケール剥離が多数観察された。このことから, マクロな スケール剥離はミクロな剥離の進展や合体により発生す るものと考えられる.
（2）ミクロなスケール剥離率（外層スケール断面剥離 率) は, 加熱温度や加熱冷却の繰り返しには影響され ず，内層スケール厚さとの間に良好な相関を示した。

(3) マクロなスケール剥離量は内層スケール厚さだけ では評価できず，加熱温度や加熱冷却の繰り返しの影響 を強く受ける傾向を示した。

\section{参 考 文 献}

1) J. Armitt, R. Holmes, M. I. Manning, D. B. Meadowcroft and E. Metcalfe: "The Spalling of SteamGrown Oxide from Superheater and Reheater Tube Steels” ,EPRI FP-686, TPS 76-655, Final Report, February (1978).

2）大塚伸夫：配管技術，10, 51 (1993).

3）大塚伸夫：住友金属, 44-3, 30 (1992).

4）火力発電技術協会関東支部ボイラチューブ事故調査委員 会：火力原子力発電, 24, 1117 (1973).

5）諸石大司（T. Moroishi）：防蝕技術 [Boshoku-Gijutsu (Corros. Eng.) ], 25, 97 (1976).

6）鈴木勝美, 浅井 治, 岩田 弘, 神林 剛：火力原子力 発電，27，27 (1976).

7）鈴木勝美, 湊 昭, 浅井 治, 岩田 弘, 神林 剛： 火力原子力発電, 32. 377 (1981).

8) W. E. Ruther and S. Greenberg : J. of the electrochem. soc., 111, 1116(1964).

9）小若正倫, 永田三郎：日本金属学会誌，36，486（1972）.

(Manuscript received December 10, 2001 ; in final form May 20, 2002) 